\title{
Can you hear me in the back?
}

\author{
Carin Canale
}
With thousands of biotech companies out there, and just as many corporate presentations, here's how to differentiate your enterprise in an increasingly crowded marketplace.

W hether the markets are bullish or bearish, the coffers full or empty, attracting financing is ever present at the top of the agenda for any emerging life science company. With competition on the rise and availability of private investment becoming more difficult to secure, it is critical that you stand out and present your story in a compelling yet succinct manner. There may not be a onesize-fits-all secret to obtaining venture capital, but there are certainly steps you can take to improve your odds. Clearly, certain nonnegotiable elements are needed to obtain venture capitalist (VC) interest, including valid technology addressing a significant, unmet need, a solid business plan with a realistic exit strategy and an experienced management team to carry out the plan. The challenge is to differentiate your firm from the thousands of life science companies who can also claim to meet those prerequisitesand the solution often lies in delivering an impressive investor presentation.

Just as there is no one-size-fits-all approach to obtaining venture capital, there isn't a single investor presentation that will work for both the 15-minute slots at investor conferences and the much longer one-on-one $\mathrm{VC}$ meetings. That said, the following 15-slide outline provides a foundation upon which investor presentations for all occasions can be built, along with a few basic principles of communication and advice from venture capitalists.

\section{Slide 1: title}

The purpose of the title or introductory slide is to briefly introduce your company without distracting from your spoken introduction. Cluttering this slide with unnecessary text, such as founding date or number of employees,

Carin Canale is president at Porter Novelli Life

Sciences, New York, New York, USA.

e-mail:ccanale@pnlifesciences.com

\begin{tabular}{|c|c|}
\hline Do & Don't \\
\hline Research the venture capitalist (VC) in advance & Bash the competition \\
\hline $\begin{array}{l}\text { Pay attention to what you say during the presession } \\
\text { banter }\end{array}$ & Hype \\
\hline Communicate & Educate or talk down \\
\hline $\begin{array}{l}\text { Be likeable (remember that they may be stuck on a } \\
\text { plane with you at some point) }\end{array}$ & Be arrogant \\
\hline State your value proposition up front & $\begin{array}{l}\text { Be vague about your technology or underestimate } \\
\text { the importance of science }\end{array}$ \\
\hline $\begin{array}{l}\text { Come prepared with sufficient data, including } \\
\text { backup slides }\end{array}$ & Deluge investors with facts \\
\hline Enjoy yourself and let it show & Act desperate for funding \\
\hline Keep the presentation within the allotted time slot & Act like you don't need money \\
\hline Be realistic about valuations in the current market & $\begin{array}{l}\text { List 'the company is undervalued' as a reason to } \\
\text { invest }\end{array}$ \\
\hline Make due diligence easy & $\begin{array}{l}\text { Overprice your rounds so you can keep stepping up } \\
\text { valuation }\end{array}$ \\
\hline $\begin{array}{l}\text { Realize that VCs are always thinking about exit } \\
\text { strategy }\end{array}$ & Give investors a reason to turn you down \\
\hline
\end{tabular}

forces the audience to read rather than pay attention to the speaker. To keep the audience's attention where it belongs, limit the content of this slide to your company logo and a tag line that quickly explains your business and, if possible, begins to differentiate your company from the competition.

A powerful spoken introduction is key to grabbing your audience's attention and setting the tempo for the rest of your presentation. To rouse your audience from the stupor that often sets in after sitting through numerous presentations, begin with a startling fact, famous quote or personal anecdote while your title slide is on the screen. If you remember one thing from this article, remember to be enthusiastic-your slide show is important, but ultimately, people buy from people, not from PowerPoint.

If you are not able to convey your enthusiasm about your company, it is difficult for investors to get excited about investing. When a VC sits down with a CEO who is obviously excited about his or her company, that enthusiasm (without being over the top) is infectious and makes a big difference in how the $\mathrm{VC}$ views the rest of the presentation (Table 1).

\section{Slide 2: investment rationale and value proposition}

The investment rationale is the single most important slide in your presentation-important enough to repeat three times.

According to the rule of communications math, $9 \times 1=0$, but $3 \times 3=1$. In other words, if you say nine messages one time each, your audience is unlikely to remember any of them, but if you say three messages three times each, your audience may remember one. This is why you begin and end with your investment rationale, which reiterates what you say during the body of the presentation. I like to call this the bookend approach.

An effective investment rationale slide explains why investors should give you money 


\begin{tabular}{|c|c|}
\hline Do & Don't \\
\hline Use only one topic per slide & Use sounds with your slide transitions \\
\hline Limit the amount of text on each slide & $\begin{array}{l}\text { Overdo the ALL CAPS, bolded, italicized or under- } \\
\text { lined text }\end{array}$ \\
\hline Choose fonts and colors that are easy to read & Use too many different fonts in a presentation \\
\hline $\begin{array}{l}\text { Remember that PowerPoint is only an accessory to } \\
\text { your presentation }\end{array}$ & $\begin{array}{l}\text { Overuse special effects that steal center stage from } \\
\text { the content of your presentation }\end{array}$ \\
\hline Remember to spell check & $\begin{array}{l}\text { Have technical difficulties-testing the presenta- } \\
\text { tion before the meeting is key }\end{array}$ \\
\hline
\end{tabular}

by listing five to seven bullet points that outline both your strengths and the direction of your presentation. Suggested topics for bullet points include core technology, product candidates, market opportunities, key partnerships or management strengths (Table 2).

\section{Slide 3: business strategy}

The business strategy slide answers the question on every potential investor's mind-how will your company make money?

VCs want to see up front how and when a company is going to make money, even if the company is early stage and profits are ten years away. There are thousands of great ideas, but only a limited number of them are supported by a sound business model.

Other subjects to address on your business strategy slide may include potential licensing opportunities to generate near-term revenue and manufacturing and commercialization strategies. You can also mention if and when you plan to partner with a larger company or how you plan to penetrate your target markets.

\section{Slides 4-10: technology and/or products}

Your technology and product slides make up the 'meat and potatoes' of your investor presentation - they are the central focus, but having too many will make your audience's eyes begin to glaze over. On the other hand, many investors are MDs or PhDs and like to see detailed data. The solution to managing the needs of your various audiences lies in backup slides.

Once you've given your presentation to a handful of investors, you tend to know which slides will lead to additional questions, so bring backup data slides to address these issues. One $\mathrm{VC}$ also recently advised me to "be up front about data that are less flattering, too, because I will find out about it, and if you don't tell me up front, how can I believe anything else you say?"

The order of your technology and products slides may vary depending on the stage of your company. Early-stage companies should begin by discussing the platform technology on which their products will be built, whereas later-stage companies should begin with the pipeline of products that provide a compelling investment opportunity. If your company has multiple products, beginning with a pipeline provides your audience with a quick overview and often elucidates how your products complement each other.

Technology slides should avoid jargon and provide a clear explanation of a company's science. Most investors agree that if you cannot explain your technology simply, you don't understand it. On the other hand, investors generally will not expect answers to very technical questions from CEOs or chief financial officers who do not have scientific backgrounds. It is perfectly acceptable to say you need to speak with your chief scientific officer before answering a question-just remember to follow up and provide the answer when you get it.

Product slides should address development status, disease indication, market size and recent data. A pet peeve of many investors, however, is a presentation that overinflates the market.

Choose data slides that are easy to comprehend even without your commentary to explain them, especially if you provide handouts of your presentation. In addition, forgo the typical scientific chart and graph titles in favor of more active titles that help to interpret the results they illustrate, such as 'Product $\mathrm{X}$ decreases tumor progression' or 'Product $\mathrm{X}$ delays need for chemotherapy'.

\section{Slide 11: intellectual property}

Contrary to popular belief, your intellectual property slide should not list every patent you've ever received. Instead, outline a patent strategy that shows you can't be touched and list only key patents.

Slide 12: management team and advisors Another frequently misused slide is the one for the management team and advisors. This slide not only should list the names of top executives and advisors, but also should include a few choice words explaining what each brings to the table, such as 'Former VP of oncology drug development at GlaxoSmithKline' or 'Closed three big pharma deals and secured $\$ 50 \mathrm{M}$ in equity financing?

Another investor pet peeve is listing advisors who are not actively working with the company. Don't talk about an advisor who is not currently involved with the company, because VCs don't want to call him or her only to hear you just paid for the name. On the other hand, if you have a phenomenal chief medical officer or world-renowned chairman, don't hesitate to bring that person to meetings with you.

\section{Slide 13-14: recent achievements and upcoming milestones}

The recent achievements slide should illustrate-especially to those audiences who have seen your presentation in the past-that you deliver on your promises. Consider including data recently presented or published, financings, key executives added, clinical trial milestones (initiation, enrollment, completion, etc.) and other significant achievements.

If there are any perceived weaknesses about your company, your anticipated milestones slide should explain how you plan to address them. For example, if your management team lacks breadth, list milestones such as 'Hire key finance and business development executives'. Just be careful to list only milestones you expect to deliver on - and be sure to include a few nearterm items that are already in the bag. This can go a long way toward establishing credibility.

\section{Slide 15: investment rationale}

A good presentation begins with a summary of what you are about to say and ends with a summary of what you've just said. Repeating your investment rationale slide at the end of your presentation also ensures that your audience is left with the key message points you are trying to convey. If you're lucky, according to the rule of communications math, they might even remember one point.

\section{Conclusion}

Following the basic format outlined above will not guarantee financing, but it will help set you apart from the crowd and leave a lasting impression with the VCs. Most importantly, remember to finish your slide presentation well in advance and take time to practice. As stressed above, enthusiasm is contagious-your slide show is important, but ultimately, PowerPoint is only a tool; you are the key. Your presentation is your story and all audiences appreciate a good story. Have fun and good luck. 